The Bangladesh Veterinarian (2010) 27(1) : 8 - 17

\title{
Effects of nutrition on production and reproduction of dairy cows in Bangladesh
}

\author{
M. M. Alam ${ }^{1 *}$ and M. J. U. Sarder \\ Department of Animal Husbandry and Veterinary Science, Faculty of Agriculture, \\ Rajshahi University, Rajshahi-6205, Bangladesh
}

\begin{abstract}
Sixty-eight cows in group A were fed 63.9 megajoules (MJ)/day, 66 in B were fed 52.9 , and 66 in $C$ were fed $51.1 \mathrm{MJ} /$ day. The mean $( \pm \mathrm{SD})$ services per pregnancy of cows in groups $\mathrm{A}, \mathrm{B}$ and $\mathrm{C}$ were $1.7 \pm 0.7,1.9 \pm 0.6$ and $2.5 \pm 0.9$, respectively. The mean calving to 1stfirst service intervals were $158.1 \pm 51.5,171.0 \pm 59.0$ and $200.0 \pm 50.3$ days, respectively. The mean milk yields were $5.8 \pm 2.6,4.5 \pm 1.9$ and $4.3 \pm 1.9$ litres/ day, respectively. Pregnancy rate was significantly $(\mathrm{P}<0.05)$ affected by breed, parity, age, body condition score (BCS) and body weight of cows. Breed and parity had no significant effect on pregnancy rate. Age, BCS and body weight had significant $(\mathrm{P}<0.05)$ affect on pregnancy rate. (Bangl. vet. 2010. Vol. 27, No. 1, 8 - 17)
\end{abstract}

\section{Introduction}

Maintaining a satisfactory fertility in cows is essential for successful dairying. Dairy farming is expanding with crossbred high yielding cows in urban and peri-urban areas. Calving interval, calving to first service interval, services per pregnancyconception and efficiency of oestrus detection are often used as measures of reproductive performance in dairy cattle. To get maximum profitability, it is very important to increase the pregnancy rate (Rice, 1980).

Ghosh et al. (1993); Jalil et al. (1995) indicated that improved feeding has a positive effect on reproductive performance. High milk production and imbalanced feeding is one of the factors for reproductive disorders in crossbred cows (Shamsuddin et al., 1988). Several studies suggest that feed supplied in particular to cows postpartum should be enough to maintain body condition, to support milk production, as well as to initiate ovarian cyclicity (Montgomery et al., 1985; Butler and Smith, 1989; Ghosh et al., 1993). The farmers usually provide better feeding through supplementation of concentrate by-products such as oil cakes, wheat bran and pulse bran only to lactating cows, as they receive immediate returns through milk sales (Ranjhan, 1999). In Bangladesh, poor fertility in cows is a major issue in cattle breeding (Alam, 1983). Adequate nutrition before calving and during postpartum period is essential if acceptable oestrus and rebreeding performance are to be achieved (Alam et al., 2001).

\footnotetext{
${ }^{1}$ Char Livelihood Programme, CLP Secretariat, Rural Development Academy Campus, Sherpur, Bogra-5842, Bangladesh

*Correspondence E-mail:- mahbub@clp-bangladesh.org
} 
Feeding practices of livestock in Bangladesh are very poor. There is no recognized standard feeding system. The farmers neither have scientific knowledge nor are following any feeding standard to satisfy the nutrient requirements of the cows. Due to lack of available grazing lands, stall-feeding is practised and sometimes cattle are tethered on the roadsides and fallow land. Seasonal and fluctuating supply of rice straw and green grass creates a great problem in feeding dairy cattle (Rahman et al., 1998).

The present study was conducted to improve the reproductive efficiency of dairy cows in Bogra area.

\section{Objective}

(a) To investigate the effect of feeding intervention on reproductive performance of dairy cows in Bogra area;

(b) To study the factors affecting the pregnancy rate of dairy cows;

(c) To evaluate feeding practices of dairy cows in the study area.

\section{Materials and Methods}

Site selection and selection of dairy farms

The study was conducted between March and December, 2008 in Bogra sadar Uupazila (Sub-district). The farms selected had 8-20 crossbred cows. Artificial insemination was practised. In order to handle the animals systematically the number of farms was restricted to 24. Identification number was given to each farm.

\section{Cow selection and grouping}

The randomly selected animals were local, or crossesanimal was local, or crosses between 1Local and Sahiwal $(\mathrm{L} \times \mathrm{SL})$, Llocal and Friesian $(\mathrm{L} \times \mathrm{F})$ or ILocal, Friesian and Sahiwal $(\mathrm{L} \times \mathrm{F} \times \mathrm{SL})$. A total of 200 cows were selected. Among them 60 were Llocal, 80 were $\mathrm{L} \times \mathrm{F}, 42$ were $\mathrm{L} \times \mathrm{SL}$ and 18 were $\mathrm{L} \times \mathrm{F} \times \mathrm{SL}$. Farms were categorized in three groups $(\mathrm{A}=68$ cows; $\mathrm{B}=66$ cows, $\mathrm{C}=66$ cows $)$ according to current feeding method.

\section{Factors studied}

Services per pregnancy, calving to first service interval and milk yield per day were recorded. Breed, age, parity, body condition score (BCS) and body weight were measured. Considering age, cows were divided into up to 4 years, 4.1 to 5.5 years, 5.6 to 7.5 years and $\geq 7.6$ years. Considering parity, cows were divided into Parity-1, Parity-2, Parity-3, Parity-4 and over. Considering BCS, cows were divided into up to 2.5, 2.6 to $3.0,3.1$ to 3.5 and 3.6 or over. Considering body weight, cows were divided into up to $200 \mathrm{~kg}$, 201 to $250 \mathrm{~kg}$, 251 to $300 \mathrm{~kg}$ and $301 \mathrm{~kg}$ or over.

\section{Feeding intervention}

The usual feeding practice in the area was rice straw, Napier grass as green roughage, and concentrate mixture, fed in the morning, noon and evening. The rice 
straw was the major source of feed for the animals. All farmers supplied Napier grass, but amount varied between farms. Crushed rice, wheat bran, rice bran and mustard oil cake were common ingredients in the concentrate mixture. Some farmers

| supplied concentrate that included crushed maize, lentil bran, pea bran and gram bran. Feed compositions in the three groups are shown in Table 1.

Table 1. Composition of feed of three different groups

\begin{tabular}{l|c|c|c}
\hline \multirow{2}{*}{ Ingredients } & Group-A & Group-B & Group-C \\
\cline { 2 - 4 } & $\begin{array}{c}\text { Feed }(\mathrm{kg} \mathrm{DM} / \mathrm{d} / \mathrm{cow}) \\
(\text { mean } \pm \mathrm{SD})\end{array}$ & $\begin{array}{c}\text { Feed }(\mathrm{kg} \mathrm{DM} / \mathrm{d} / \mathrm{cow}) \\
(\text { mean } \pm \text { SD) }\end{array}$ & $\begin{array}{c}\text { Feed (kg DM/d/cow) } \\
(\text { mean } \pm \text { SD) }\end{array}$ \\
\hline Rice straw & $3.8 \pm 0.16$ & $4.20 \pm 0.33$ & $4.60 \pm 0.20$ \\
Napier grass & $1.8 \pm 0.13$ & $1.00 \pm 0.07$ & $0.50 \pm 0.02$ \\
Concentrate & $3.2 \pm 0.06$ & $2.90 \pm 0.09$ & $2.80 \pm 0.04$ \\
mixture* & $8.8 \pm 0.22$ & & $7.90 \pm 0.19$ \\
\hline Total feed & & $8.10 \pm 0.31$ & $10 \%$, \\
\hline
\end{tabular}

* Concentrated mixture of group-A: crushed rice and crushed maize $30 \%$, wheat bran $10 \%$, rice bran $20 \%$, lentil bran, pea bran \& gram bran $20 \%$ and mustard oil cake $20 \%$

* Concentrated mixture of group-B: Crushed rice $28 \%$, wheat bran $13 \%$, rice bran $25 \%$, gram bran $14 \%$ and mustard oil cake $20 \%$

* Concentrated mixture of group-C: Crushed rice 30\%, wheat bran $25 \%$, rice bran $25 \%$ and mustard oil cake $20 \%$

\section{Collection of feed samples and chemical analysis}

Representative samples of feed in each group were collected in polythene bags containing $200-250 \mathrm{~g}$, and taken to laboratory for chemical analysis. The roughage samples were dried and ground to pass through two $\mathrm{mm}$ sieve and kept in the polythene bags for chemical analysis. Chemical composition for dry matter (DM), crude protein $(\mathrm{CP})$, crude fibre $(\mathrm{CF})$, ether extract (EE) and total ash (TA) were determined following the methods of AOAC (1995). Organic matter (OM) digestibility and metabolizable energy (ME) were estimated following the methods of Menke and Steingass (1988).

\section{Nutrient requirements and feeding intervention}

The daily nutrient requirements such as digestible crude protein (DCP) and ME were estimated based on the ARC (1980) standard considering body weight and milk production. Supply of DCP and ME were calculated from amount of supplied feed ingredients and results of chemical analysis. Group wise average body weight and daily milk production of cows, ME and DCP requirement and supply are depicted in Table 2.

\section{Data collection}

Reproductive data were collected for 10 months. A formatted register was supplied to each farmer and closely and frequently monitored by visits. Farmers 
were given suggestion on management of reproduction and data recording. Services per pregnancy, calving to first service interval and milk yield per day were recorded. Pregnancy diagnosis was performed by rectal palpation of genital tract.

Table 2. Body weight, milk production, and ME and DCP requirement and supply

\begin{tabular}{|c|c|c|c|c|c|c|}
\hline \multirow{2}{*}{$\begin{array}{l}\text { Feeding } \\
\text { group }\end{array}$} & \multirow{2}{*}{$\begin{array}{c}\text { Body weight } \\
(\mathrm{kg}) \\
(\text { mean } \pm \mathrm{SD})\end{array}$} & \multirow{2}{*}{$\begin{array}{l}\text { Milk production } \\
\text { (litres/day) } \\
\text { (mean } \pm \mathrm{SD})\end{array}$} & \multicolumn{2}{|c|}{ ME \& DCP requirement } & \multicolumn{2}{|c|}{ ME \& DCP supply } \\
\hline & & & $\begin{array}{c}\mathrm{ME} \\
\text { (MJ/day) }\end{array}$ & $\begin{array}{c}\text { DCP } \\
\text { (g/day) }\end{array}$ & $\begin{array}{c}\text { ME } \\
\text { (MJ/day) }\end{array}$ & $\begin{array}{c}\text { DCP } \\
\text { (g/ day) }\end{array}$ \\
\hline A & $\begin{array}{c}255.6 \pm 55.8 \\
(\mathrm{n}=68)\end{array}$ & $\begin{array}{c}5.8 \pm 2.6 \\
(\mathrm{n}=68)\end{array}$ & 63.3 & 475 & 63.9 & 524 \\
\hline B & $\begin{array}{c}249.5 \pm 52.6 \\
(\mathrm{n}=66)\end{array}$ & $\begin{array}{c}4.5 \pm 1.9 \\
(\mathrm{n}=66)\end{array}$ & 55.9 & 400 & 52.9 & 445 \\
\hline C & $\begin{array}{c}250.4 \pm 58.4 \\
(\mathrm{n}=66)\end{array}$ & $\begin{array}{l}4.3 \pm 1.9 \\
(\mathrm{n}=66)\end{array}$ & 54.7 & 387 & 51.1 & 409 \\
\hline
\end{tabular}

Statistical analyses

The data were entered into MS Excel spreadsheet, and transferred to analytical software SPSS for descriptive analysis. General Linear Model analysis was done to measure the strength of association between the potential influencing factors. Duncan Multiple Range Test (DMRT) was used for test of significance of means with unequal subclass number (Kramer, 1956). The outcome variables were services per conception, calving to first service interval and milk yield per day. Univariate Analysis of Variance was used to test significance of effect of breed, parity, age, BCS and body weight on pregnancy rate.

\section{Results and Discussion}

ME supply in group A was slightly higher than the requirement whereas in groups B and C it was slightly less. DCP supply was higher than the requirement in all groups.

\section{Reproductive and productive performances}

The effects of feeding intervention on services per pregnancy, calving to first service interval and milk yield per day are presented in Table 3.

\section{Services per pregnancy}

Number of services per pregnancy was significantly $(\mathrm{P}<0.01)$ lower in group-A than in group-B and group-C. Ahmed (2006) observed that services for each successful pregnancy decreased significantly $(P<0.05)$ with improved feeding in Baghabarighat area. There was significant $(P<0.05)$ variation in services per pregnancy between the breeds. The number of services per pregnancy was similar to those reported by Ghosh (1995), who reported 1.6 to 1.7 for crossbred cows. The 
effects of nutrient deficits on pregnancy are largely mediated through changes in energy balance. Surplus rumen-degradable protein and an insufficiency of manganese may lower pregnancy, but important nutrient deficiencies shown to reduce pregnancy are reduced DM intake and negative energy balance (Ferguson, 1991).

Table 3. Effects of feed on productive and reproductive traits

\begin{tabular}{l|c|c|c|c}
\hline \multirow{2}{*}{ Traits $\pm \mathrm{SD}$} & \multicolumn{3}{|c|}{ Feeding } & $\begin{array}{c}\text { Level of } \\
\text { significance }\end{array}$ \\
\cline { 2 - 4 } & Group-A & Group-B & Group-C & \\
\hline Services per pregnancy & $\begin{array}{c}1.7 \pm 0.7^{\mathrm{a}} \\
(\mathrm{n}=68)\end{array}$ & $\begin{array}{c}1.9 \pm 0.6^{\mathrm{b}} \\
(\mathrm{n}=66)\end{array}$ & $\begin{array}{c}2.52 \pm 0.9^{\mathrm{c}} \\
(\mathrm{n}=66)\end{array}$ & $\mathrm{P}<0.001$ \\
Calving to first service & $\begin{array}{c}158.1 \pm 51.5^{\mathrm{a}} \\
(\mathrm{n}=62)\end{array}$ & $\begin{array}{c}171.0 \pm 59.0^{\mathrm{a}} \\
(\mathrm{n}=60)\end{array}$ & $\begin{array}{c}200.0 \pm 50.3^{\mathrm{b}} \\
(\mathrm{n}=66)\end{array}$ & $\mathrm{P}<0.01$ \\
interval (days) & $\begin{array}{c}\left.\mathrm{n}=6.6^{\mathrm{b}}\right) \\
\text { Milk yield (litres/day) }\end{array}$ & $\begin{array}{c}5.5 \pm 1.9^{\mathrm{a}} \\
(\mathrm{n}=68)\end{array}$ & $\begin{array}{c}4.3 \pm 1.9^{\mathrm{a}} \\
(\mathrm{n}=66)\end{array}$ & $\mathrm{P}<0.01$ \\
& $(\mathrm{n}=66)$ & \\
\hline
\end{tabular}

abc values having different superscripts differed significantly. Parentheses indicate the total number of observations, $\mathrm{SD}=$ Standard deviation

\section{Calving to first service interval}

Improved feeding significantly $(\mathrm{P}<0.05)$ reduced the calving to first service interval when group A was compared to group-B and C. Ahmed (2006) observed that feeding significantly $(\mathrm{P}<0.01)$ reduced the calving to first service interval. Calving to first oestrus is an important parameter affected by feeding (Dziuk and Bellows, 1983). Cows with excessive weight loss and severe negative energy balance have irregular oestrus periods and longer time to first ovulation and first breeding (Ferguson, 1991).

Milk yield

The milk yield was significantly $(\mathrm{P}<0.05)$ affected by feeding intervention. Milk yield in group-A was higher than in group-B and C. Ahmed (2006) observed that feeding significantly $(\mathrm{P}<0.01)$ increased the milk yield. Productive and reproductive performances of crossbred cows were studied in Baghabarighat on a traditional feeding and management system by Khan and Khatun (1998). The average milk yield of some crossbred cows was significantly $(\mathrm{P}<0.01)$ higher than in some other crossbreds and was affected by nutrition. The daily milk yield was 8.1, 9.7 liters and 7.4 liters for SL $\times$ Pabna, $\mathrm{F} \times$ Pabna and Pabna $\times$ Pabna genetic groups, respectively. Sarker $(1995)$ found significant $(\mathrm{P}<0.01)$ effect of feeding on the milk yield of local and crossbred cows in Shahjadpur area. Mishra et al. (2004) studied the effect of supplementing calcium salts of mustard oil fatty acids and heat-treated crushed mustard seeds in crossbred cows. Milk yield was increased $(\mathrm{P}<0.05)$ by $7.1-9.5 \%$. 
Effects of breed, parity, age, BCS and Body weight on pregnancy rate

Effects of breed on pregnancy rate

The effects of breed and feeding interventions on pregnancy rate are in Table 4. The pregnancy rate was significantly $(\mathrm{P}<0.05)$ affected by feeding interventions. Pregnancy rate of cows of group-A was higher than in group-B and C. Pregnancy rate of different breeds was not significantly different. The findings of the present study are in agreement with those of Gwazdauskas et al. (1975); Ghosh (1990; 1995), and in partial agreement with the reports of Reo et al. (1992); Cuong et al. (1993). Alam (1991) observed similar pregnancy rates for different genotypes, although, it varied within the same breed in different areas.

Table 4. Pregnancy rates, breeds and feeding groups

\begin{tabular}{c|l|c|c|c|c|c}
\hline \multirow{2}{*}{$\begin{array}{c}\text { Feed } \\
\text { groups }\end{array}$} & $\begin{array}{c}\text { Calculating } \\
\text { factors }\end{array}$ & \multicolumn{6}{c}{ BREEDS } \\
\cline { 3 - 8 } & Local & $\begin{array}{c}\text { Local x } \\
\text { Friesian }\end{array}$ & $\begin{array}{c}\text { Local x } \\
\text { Sahiwal }\end{array}$ & $\begin{array}{c}\text { Local x Friesian } \\
\text { x Sahiwal }\end{array}$ & Total \\
\hline Group-A & Number & 20 & 26 & 16 & 6 & 68 \\
& $\%$ within breed & $60.0 \%$ & $53.9 \%$ & $37.5 \%$ & $66.7 \%$ & $52.9 \%$ \\
\hline Group-B & Number & 20 & 26 & 14 & 6 & 66 \\
& $\%$ within breed & $40.0 \%$ & $38.5 \%$ & $42.9 \%$ & $50.0 \%$ & $40.9 \%$ \\
\hline Group-C & Number & 20 & 28 & 12 & 6 & 66 \\
& $\%$ within breed & $40.0 \%$ & $35.7 \%$ & $16.7 \%$ & $16.7 \%$ & $31.8 \%$ \\
\hline
\end{tabular}

Effects of parity and feeding on pregnancy rate

The effects of parity and feeding on pregnancy rate are in Table 5. Pregnancy rate was significantly $(\mathrm{P}<0.05)$ affected by feeding interventions. Parity did not significantly affect pregnancy rate. Hasan $(2008)$ found significant $(\mathrm{P}<0.01)$ effect of parity on pregnancy rate.

Table 5. Pregnancy rates, parity and feeding groups

\begin{tabular}{c|l|c|c|c|c|c}
\hline \multirow{2}{*}{$\begin{array}{c}\text { Feed } \\
\text { groups }\end{array}$} & Calculating factors & \multicolumn{5}{c}{ PARITY } \\
\cline { 3 - 7 } & & 1 & 2 & 3 & $\geq 4$ & Total \\
\hline Group-A A Number & 20 & 24 & 14 & 10 & 68 \\
& $\%$ within parity & $50.0 \%$ & $66.7 \%$ & $42.9 \%$ & $40.0 \%$ & $52.9 \%$ \\
\hline Group-B & Number & 18 & 26 & 20 & 2 & 66 \\
& $\%$ within parity & $33.3 \%$ & $38.5 \%$ & $50.0 \%$ & $50.0 \%$ & $40.9 \%$ \\
\hline Group-C & Number & 16 & 32 & 10 & 8 & 66 \\
& $\%$ within parity & $37.5 \%$ & $34.4 \%$ & $20.0 \%$ & $25.0 \%$ & $31.8 \%$ \\
\hline
\end{tabular}


| Effects of age on pregnancy rate

The effects of age on pregnancy rate are in Table 6. Pregnancy rate was significantly $(\mathrm{P}<0.05)$ affected by age. In group A, pregnancy rate of cows of $\leq 4$ years age group was highest (57.2\%) followed by $4.1-5.5,5.6-7.5$ and $\geq 7.6$ years. In group $B$, pregnancy rate of cows of $4.1-5.5$ years age was highest (58.3\%) followed by $\geq 7.6$, $5.6-7.5$ and $\leq 4$ years. In group $C$ pregnancy rate of cows of 4.1-5.5 years was highest $(38.5 \%)$ followed by $\leq 4,5.6-7.5$ and $\geq 7.6$ years. Hasan (2008) found significant $(\mathrm{P}<0.01)$ effect of age on pregnancy rate. These findings were in partial agreement with Spalding et al. (1975). They reported a slight increase in the fertility of cows up to 3 to 4 years of age and a decline after 4 years. They also found a marked decline in fertility in cows over 7 years of age. De Kruif (1978) observed pregnancy rate following the first insemination to be lower over 7 years of age. Barkett (1986) similarly found a decrease in fertility in cows older than 7 years. Holmes and McClintoc (1994) observed that fertility peaked from 6 and 7 years of age and then declined.

Table 6. Pregnancy rate, age and feeding groups

\begin{tabular}{c|l|cccccc}
\hline \multirow{2}{*}{$\begin{array}{c}\text { Feed } \\
\text { group }\end{array}$} & Calculating factors & \multicolumn{5}{c}{ AGE (years) } \\
\cline { 3 - 7 } & & $\leq 4$ & 4.1 to 5.5 & 5.6 to 7.5 & $\geq 7.6$ & Total \\
\hline Group-A & Number & 14 & 22 & 20 & 12 & 68 \\
& \% within age group & $57.1 \%$ & $54.6 \%$ & $50.0 \%$ & $50.0 \%$ & $52.9 \%$ \\
\hline Group-B & Number & 14 & 24 & 26 & 2 & 66 \\
& $\%$ within age group & $28.6 \%$ & $58.3 \%$ & $30.8 \%$ & $50.0 \%$ & $40.9 \%$ \\
\hline Group-C & Number & 12 & 26 & 24 & 4 & 66 \\
& \% within age group & $33.3 \%$ & $38.5 \%$ & $29.8 \%$ & $0.0 \%$ & $31.8 \%$ \\
\hline
\end{tabular}

Effects of body condition score (BCS) on pregnancy rate

The effects of body condition score on pregnancy rate are in Table 7. Pregnancy rate was significantly $(\mathrm{P}<0.05)$ affected by $\mathrm{BCS}$. In group $\mathrm{A}$, pregnancy rate of cows of 3.1 - 3.5 BCS was highest (66.7\%) followed by $\leq 2.5,2.6-3.0$ and $\geq 3.6$. In group B, pregnancy rates of cows of $2.6-3.0$ and $3.1-3.5$ BCS groups were highest $(50.0 \%)$ followed by $\leq 2.5$ and $\geq 3.6$. In group $C$ pregnancy rate of cows of $2.6-3.0$ was highest (33.3\%) followed by $2.5 \geq 3.1-3.5$ and $\geq 3.6$ BCS groups. Hasan (2009) found significant $(\mathrm{P}<0.01)$ effect of pregnancy rate on different BCS groups. Cows having BCS 3.1 - 4.0 (very good condition) showed better pregnancy rate.

\section{Effects of body weight on pregnancy rate}

The effects of body weight on pregnancy rate are in Table 8. Pregnancy rate was significantly $(\mathrm{P}<0.05)$ affected by body weight. In group $\mathrm{A}$, pregnancy rate of cows of $\leq 200 \mathrm{~kg}$ body weight was highest (78.6\%) followed by $201-250,251-300$ and $\geq$ 301. In group B pregnancy rate of cows of $201-250 \mathrm{~kg}$ was highest (52.4\%) followed 
by $\leq 200,251-300$ and $\geq 301$. In group $C$ pregnancy rate of cows of $\leq 200 \mathrm{~kg}$ was highest $(40.0 \%)$ followed by 251-300, $\geq 301$ and 201-250. Hasan (2008) found significant $(\mathrm{P}<0.01)$ effect of body weight on pregnancy rate. Saacke et al. (1991) reported that the heavier cows had higher pregnancy rates.

Table 7. Pregnancy rate, body condition score (BCS) and feeding groups

\begin{tabular}{l|l|cccccc}
\hline Feed group & Calculating factors & \multicolumn{5}{|c}{ Body condition score (BCS) } \\
\cline { 3 - 7 } & & $\leq 2.5$ & 2.6 to 3.0 & 3.1 to 3.5 & $\geq 3.6$ & Total \\
\hline Group-A & Number & 24 & 30 & 8 & 6 & 68 \\
& $\%$ within BCS group & $50.0 \%$ & $47.1 \%$ & $66.7 \%$ & $30.3 \%$ & $52.9 \%$ \\
\hline Group-B & Number & 20 & 34 & 8 & 4 & 66 \\
& $\%$ within BCS group & $35.0 \%$ & $50.0 \%$ & $50.0 \%$ & $35.0 \%$ & $40.9 \%$ \\
\hline Group-C & Number & 20 & 32 & 6 & 8 & 66 \\
& $\%$ within BCS group & $33.3 \%$ & $40.0 \%$ & $33.3 \%$ & $20.0 \%$ & $31.8 \%$ \\
\hline
\end{tabular}

Effects of body weight on pregnancy rate

The effects of body weight on pregnancy rate are in Table 8. Pregnancy rate was significantly $(\mathrm{P}<0.05)$ affected by body weight. In group $\mathrm{A}$, pregnancy rate of cows of $\leq 200 \mathrm{~kg}$ body weight group was highest (78.6\%) followed by $201-250,251-300$ and $\geq 301$. In group B pregnancy rate of cows of $201-250 \mathrm{~kg}$ group was highest $(52.4 \%)$ followed by $\leq 200,251-300$ and $\geq 301$. In group C pregnancy rate of cows of $\leq$ $200 \mathrm{~kg}$ group was highest $(40.0 \%)$ followed by 251-300, $\geq 301$ and 201-250. Hasan (20089) found significant $(\mathrm{P}<0.01)$ effect of body weight on pregnancy rate. Saacke et al. (1991) reported that the heavier cows had higher pregnancy rates.

Table 8. Pregnancy rate, body weight and feeding groups

\begin{tabular}{|c|c|c|c|c|c|c|}
\hline \multirow[t]{2}{*}{ Feed group } & \multirow{2}{*}{$\begin{array}{l}\text { Calculating } \\
\text { factors }\end{array}$} & \multicolumn{5}{|c|}{ Body weight $(\mathrm{Kg})$} \\
\hline & & $\leq 200$ & 201 to 250 & 251 to 300 & $\geq 301$ & Total \\
\hline \multirow[t]{2}{*}{ Group-A } & Number & 14 & 23 & 19 & 12 & 68 \\
\hline & $\begin{array}{l}\% \text { within body } \\
\text { weight group }\end{array}$ & $78.6 \%$ & $52.2 \%$ & $42.1 \%$ & $41.7 \%$ & $52.9 \%$ \\
\hline \multirow[t]{2}{*}{ Group-B } & Number & 19 & 21 & 16 & 10 & 66 \\
\hline & $\begin{array}{l}\% \text { within body } \\
\text { weight group }\end{array}$ & $36.8 \%$ & $52.4 \%$ & $31.3 \%$ & $40.0 \%$ & $40.9 \%$ \\
\hline \multirow[t]{2}{*}{ Group-C } & Number & 15 & 16 & 20 & 15 & 66 \\
\hline & $\begin{array}{l}\% \text { within body } \\
\text { weight group }\end{array}$ & $40.0 \%$ & $25.0 \%$ & $35.0 \%$ & $26.7 \%$ & $31.8 \%$ \\
\hline
\end{tabular}

\section{Conclusions}

It may be concluded that feeding intervention had significant $(\mathrm{P}<0.01)$ influence on services per pregnancy, calving to first service interval $(\mathrm{P}<0.05)$, and milk 
production $(\mathrm{P}<0.05)$. Proper feeding improved the reproductive and productive traits. Pregnancy rate was significantly $(\mathrm{P}<0.05)$ affected by age, $\mathrm{BCS}$ and body weight. Breed and parity effects were not significant.

\section{References}

Ahmed TU 2006: Studies on nutritional status of dairy cows of Bangladesh and improvement their productive and reproductive performance in Baghabarighat area through nutritional manipulation. PhD Thesis, Department of Animal Nutrition, Faculty of Animal Husbandry, Bangladesh Agricultural University, Mymensingh.

Alam MGS, Ghosh A, Mondal AK, Akbar MA 2001: Supplementation and puberty of Zebu calves of Bangladesh. The Bangladesh Veterinarian 18 1-8.

Alam MGS 1991: Studies on current reproductive status with special emphasis on endocrine disorders in cows - A research report, Department of Surgery and Obstetrics, Faculty of Veterinary Science, Bangladesh Agricultural University, Mymensingh.

Alam MGS 1983: Research on animal reproduction at the Bangladesh Agricultural University, Mymensingh. Livestock Advisor 8 15-18.

AOAC 1995: Official Methods of Analysis. (16 th Edn), Association of Official Analytical Chemist, Washington DC, USA.

ARC 1980: The Nutritional Requirements of Ruminant Livestock. $4^{\text {th }}$ edn. CAB International, Wallingford, USA pp. 73-310.

Barkett 1986: Dairy merit of temperate and tropical cross-bred cows at the Sylhet government farm. Bangladesh Veterinary Journal 29 57-61.

Butler WR, Smith RD 1989: Interrelationships between energy balance and postpartum reproductive function in the dairy cattle. Journal of Dairy Science 72 767-783.

Cuong LX, Tan LV, Dung CA, Chung DP, Long VN 1993: Study on the effects of season and genotypes on the reproductive performance in crossbred cattle. FAO/IAEA Proceeding of the Final Research Co-ordination meeting, Bangkok, Thailand. February 1-5.

De Kruif A 1978: Factors influencing the fertility of a cattle population. Journal of Reproduction and Fertility 54 507-518.

Dziuk PJ, Bellows RW 1983: Management of reproduction in beef cattle, sheep and pig. Journal of Animal Science 57 355-360.

Ferguson JD 1991: Nutrition and Reproduction in Dairy cows. Veterinary Clinics of North America. Food Animal Practice $\mathbf{5 4}$ 507-518.

Ghosh 1990: Reproductive performance of Zebu, cows and their crosses with references to progesterone concentrationsptions during the oestrous cycle, early pregnancy and post partum period,. MSc Thesis, Department of Surgery and Obstetrics, Faculty of Veterinary Science, Bangladesh Agricultural University, Mymensingh.

Ghosh A, Alam MGS, Akbar MA 1993: Effect of urea-molasses-mineral block supplementation in postpartum ovarian activity in zebu cows. Animal Reproduction Science 31 61-67.

Ghosh DK 1995: Economic traits of crossbred cattle in the small dairy enterprises of Gazipur district. MS Thesis, Department of Physiology, Faculty of Veterinary Science, Bangladesh Agricultural University, Mymensingh, Bangladesh. 
Gwazdauskas FC, Wilcox CJ, Thatcher WW 1975. Environmental and managemental factors affecting conception rate in a subtropical climate. Journal of Dairy Science $\mathbf{5 8}$ 88-92.

Hasan MZ 2008: Pregnancy Rate at First Service Artificial Insemination in Dairy Cows. MS Thesis, Department of Physiology, Faculty of Veterinary Science, Bangladesh Agricultural University, Mymensingh, Bangladesh.

Holmes I, McClintoc S 1994: The determination of individual bull calving rates and factors affecting dairy cow. South African Veterinary Association 66 74-76.

Jalil MA, Sarker N, Paul DC, Khan AA 1995: Status of existing husbandry practices of dairy cattle at Manikganj, Bangladesh. Bangladesh Journal of Animal Science 24 71-80.

Khan MKI, Khatun MJ 1998. Performance of $F_{1}$ crossbred cows at Baghabarighat milk shed area. Bangladesh Journal of Animal Science 27 183-186.

Kramer CY 1956: Examination of multiple range tests to group means with unequal numbers of replication. Biometrics 12 307-310.

Menke KH, Steingass H 1988: Estimation of the energetic feed value obtained from chemical analysis and in vitro gas production using rumen fluid. Animal Research and Development 28 7-55.

Mishra S, Thakur SS, Raikwar R 2004: Milk production and composition in crossbred cows fed calcium salts of mustard oil fatty acids. Indian Journal of Animal Nutrition 21 22-25.

Montgomery GW, Scott IC, Hudson N 1985: An interaction between season of calving and nutrition on the resumption of ovarian cycles in postpartum beef cattle. Journal of Reproduction and Fertility 73 45-50.

Rahman MM, Akhtar S, Hossain MM 1998: The availability of livestock feeds and feeding practices followed by the farmer of some areas of Mymensingh District. Bangladesh Journal of Animal Science 27 119-126.

Ranjhan SK 1999: Dairy feeding system. In: Smallholder dairying in the tropics. Falvey L and Chantalakhana C (editors) pp. 117-132.

Reo AVM, Naidu MS, Murthy YN 1992: Effects of breed type and season on conception rates in cows. World Review of Animal Production 27 3, 7 \& 23-25.

Rice L 1980: Reproductive health management in beef cows. In: Current Therapy in Theriogenology. DA Morrow (ed.), WB Saunders Company, Philadelphia, London, Toronto, pp. 534-545.

Saacke RG, Dejarnett GM, Nebel RL, Nadir S 1991: Assessing bull fertility. In: Proceeding Annual Meeting of Society for Theriogenology. San Diego, California, USA pp. 56-69.

Sarker MA 1995: Economic analysis of dairy cattle enterprise and its pattern of contribution to farm income in a selected area of Bangladesh. MS Thesis, Department of Agricultural Economics, Faculty of Agricultural Economics and Rural Sociology, Bangladesh Agricultural University, Mymensingh, Bangladesh.

Shamsuddin M, Alam MGS, Ahmed JU 1988: Reproductive disorders of crossbred cows. Bangladesh Veterinary Journal 22 21-28.

Spalding RW, Everett RW, Foote RH 1975: Fertility in New York artificially inseminated Holstein herds in dairy herd improvement. Journal of Dairy Science 58 718-723. 